\title{
CIRCULATION INDEX AS A QUANTITATIVE INDICATOR OF ANGIOGENESIS IN CHORIOALLANTOIC MEMBRANE OF CHICKEN BROILERS
}

\author{
Zoran RUŽIĆ , Zdenko KANAČKI, Dragan ŽIKIĆ, Gordana UŠĆEBRKA ${ }^{1}$, Jovan MIR $\check{C} E A^{2}$
}

\begin{abstract}
Summary: Chorioallantoic membrane (CAM) is an extraembryonic membrane very frequently used for in vivo studies in various researches. Since researches require a fast method for quantifying the CAM angiogenic response, there is a need to develop a new precise and unbiased method of quantification of angiogenesis in CAM, which would be easy to perform and suitable for analysis of a large number of samples. The objective of this paper is to apply a new method of quantification of angiogenesis in investigation of the development of blood vessels in the CAM, in particular days of embryonic life considered essential for CAM development. The present research included 75 fertilized eggs of heavy hybrid Ross 308. CAM sampling for stereological analyses was in key phases of embryonic development, namely on the $12^{\text {th }}, 15^{\text {th }}$ and $19^{\text {th }}$ day. The results of the present investigation show that the increase in embryonic age results in increase in circulation index, which is also an indicator of angiogenic processes developing in CAM. The lowest value of circulation index (0.1952) was recorded on the first sampling day (E12), while the highest value (0.2666) was recorded on the last sampling day (E19). This method may be applied in researching different factors which affect angiogenesis in CAM.
\end{abstract}

Key words: chorioallantoic membrane, circulation index, angiogenesis, angiogenic response.

\section{INTRODUCTION}

Selection in chicken breeding brought a rapid increase in fattening broilers and a high conversion of food, while on the other hand broilers are less resistant to adverse ambient and climate conditions. Good results in chicken breeding emanate not only from a good postnatal management, but also from a prenatal one. Apparently, it is very important to optimize the period of incubation which is an important phase of the overall growth (Hulet, 2007). Incubation factors which affect the quality of chickens are temperature, air humidity, egg turning, certain gasses concentrations (Verhoelst et al., 2011a), and according to the reports of several recent studies, specific types of lighting, as well (Kanački et al., 2011). A great number of factors regulating embryonic development may be used to optimize this period in a better way, for instance increased levels of $\mathrm{CO}_{2}$ concentration in the early period of incubation are reported to improve the body mass of chickens, hatching time and the angiogenesis in chorioallantoic membrane (CAM) (Verhoelst et al., 2011b; De Smit et al. 2006). Since CAM is the organ responsible for gas exchange, differences in angiogenesis may have a major impact on the metabolism of the embryo and subsequently on the embryonic development and later production characteristics in the postnatal period. Consequently, angiogenesis in CAM may be used to monitor the development of chicken embryo due to optimization of certain incubation factors.

\footnotetext{
${ }^{1}$ Zoran Ružić, DVM, PhD student, Zdenko Kanački, DVM, MSc, PhD, Associate Professor, Dragan Žikić, PhD, Full Professor, Gordana Ušćebrka, PhD, Full Professor. University of Novi Sad, Faculty of Agriculture, Trg Dositeja Obradovića 8, Novi Sad, Serbia

2 Jovan Mirčeta, DVM, PhD. Public Company „Vojvodinašume“, Preradovićeva 2, Petrovaradin, Serbia.

This research is a part of project supporting by the Ministry of Education, Science, and Technological Development of Serbia (Project No. TR 31033)

Corresponding author: Zoran Ružić, e-mail: ruziczoran.1991@gmail.com
} 
Chicken embryo CAM is formed between the $4^{\text {th }}$ and $5^{\text {th }}$ day of embryonic development (E4-E5), when the outer layer of the mesoderm of the allantois (visceral mesoderm) fuses with the mesoderm of the chorion (somatic mesoderm). A plexus of blood vessels is formed in this bilayer, which is connected to the embryonic circulation with two allantoic arteries and one allantoic vein (Ribatti, 2016). The role of CAM is the gas exchange between the embryo and the atmosphere and thus CAM assumes the function of lungs during the embryonic development (Romanoff, 1960). Allantois is a synthesized waste collector in the embryo, primarily of urea and later of uric acid (Ribatti, 2016). Moreover, CAM has a role in sodium and chlorine transportation from allantoic sac where uric products are dissolved; it also has an essential role in osteosynthesis because it conducts calcium from the eggshell to the embryo (Tuan, 1987).

Visibility, accessibility and fast development of CAM are all advantages which enable this structure to be used as a model for various investigations. CAM is widely used in angiogenesis studies, the studies on tumour growth and metastases investigations, as well as in pharmacological and toxicological investigations. Another advantage of this model is its low cost and the fact that this kind of experiment is ethically more acceptable than the experiments on adult forms.

Different methods have been developed so far to quantify CAM angiogenic response, either in ovo, by the use of a window in the eggshell, or ex ovo when the whole contents of the egg is placed in a petri dish (Nowak-Sliwinska et al., 2014). Many of these methods are complex and require expensive equipment; in addition, it is difficult to analyse a great number of samples. Hence, a new precise and objective method, which is both easy and relatively fast, needs to be developed to quantify angiogenesis in the CAM. The objective of the present paper is to apply a new method of quantification of angiogenesis to investigate the development of blood vessels in the CAM, in particular days of embryonic life considered essential for CAM development.

\section{MATERIAL AND METHODS}

The present research was conducted on 75 fertilized eggs of heavy hybrid Ross 308 from a 54-week-old broiler breeder flock. The incubator with a capacity of 75 eggs was used. The incubation temperature was set at $37.9^{\circ} \mathrm{C}$ throughout the embryonic development, controlled with an electric thermostat "Termoregulator ET-01" manufactured by "Pro-Elektro", Novi Sad, Serbia. Relative air humidity was set at $50 \%$ to $60 \%$ until the $18^{\text {th }}$ day of embryonic development, and at $75 \%$ from the $19^{\text {th }}$ day of embryonic development until the end of incubation. The ventilation was adjusted according to the phase of embryonic development.

The sampling of eggs to obtain the CAM for the purpose of stereological analysis took place in critical phases of stereological analysis by random sampling. On the $12^{\text {th }}, 15^{\text {th }}$ and $19^{\text {th }}$ day of embryonic development, 10 eggs were taken per day. All randomly chosen eggs contained vital embryos with developed CAM which enclosed the whole embryo.

The eggshells of the eggs taken on the $12^{\text {th }}, 15^{\text {th }}$ and $19^{\text {th }}$ embryonic development day were removed for CAM preparation. It was carried out by careful manual removal of the eggshell so that blood vessels in the CAM would not be damaged. The vascular network in the CAM of the embryo was photographed using a digital camera "Panasonic Lumix DMC-LS80", Japan. The pictures were then processed using stereological principles in the software Scion Image 4.0, Scion Corporation, which was used to calculate the circulation index of each sample by the multipurpose test-system M42 (Burity et al., 2004). The same part and the same CAM area were analysed while photographing to avoid mistakes due to different circulation in different CAM parts.

The circulation index was calculated using the following expression:

$$
\mathrm{I} p=\mathrm{P}(\mathrm{ks}) / \mathrm{P}(\mathrm{cam})
$$

Ip - Circulation index

$\mathrm{P}(\mathrm{ks})$ - Total number of pixels corresponding to CAM blood vessels

$\mathrm{P}(\mathrm{cam})$ - Total number of pixels corresponding to CAM

In the paper, the circulation index is shown as an average value along with the provided variance. The statistical analysis was performed using a PC and the Microsoft Office 2013 set of applications. The variance analysis was carried out using the F-test, while the average CAM circulation index values on different days were compared using the Student's t-test. 


\section{RESULTS}

By means of stereological processing of pictures and the calculations derived using the expression, the CAM circulation index values were obtained and they are provided in Table 1. The circulation index is represented as an average value and it is expressed for the examined days of embryonic development.

Table 1. CAM circulation index for the defined days of embryonic development

\begin{tabular}{|c|c|c|}
\hline \multirow{2}{*}{ Day of embryonic development } & \multicolumn{2}{|c|}{ CAM circulation index } \\
\cline { 2 - 3 } & Average value & Variance \\
\hline E12 & $0.1952^{\mathrm{A}, \mathrm{a}}$ & 0.0013 \\
\hline $\mathrm{E} 15$ & $0.2261^{\mathrm{A}, \mathrm{B}, \mathrm{b}}$ & 0.0009 \\
\hline $\mathrm{E} 19$ & $0.2666^{\mathrm{B}, \mathrm{a}}$ & 0.0038 \\
\hline
\end{tabular}

A-B Means within a column with no common superscript differ significantly $(\mathrm{P}<0.01)$.

${ }^{\mathrm{a}-\mathrm{b}}$ Means within a column with no common superscript differ significantly $(\mathrm{P}<0.05)$.

The lowest circulation index value was detected on the $12^{\text {th }}$ day of embryonic development $(E 12)$, while the highest value was detected on the $19^{\text {th }}$ day of embryonic development (E19). Based on the derived results, it can be concluded that as the embryonic development progresses, the circulation index increases, i.e. the CAM vascular system is extended to a larger surface when compared to the entire CAM surface.

The statistical analysis determined that there was a statistically significant difference in circulation index values between E12 and E15, as well as between E15 and E19 at the level of significance P<0.05, while between E12 and E19 the statistically significant difference at the level of significance was $\mathrm{P}<0.01$.

The images 1-3 show the appearance of the circulatory system for several CAMs in the embryonic development days on which it was analysed .

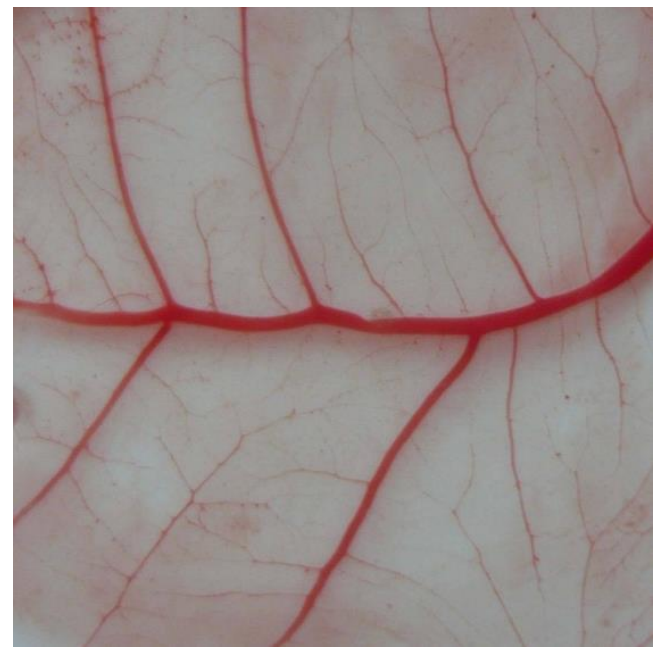

Image 1 . The representation of the circulatory system on the $12^{\text {th }}$ day of embryonic development 


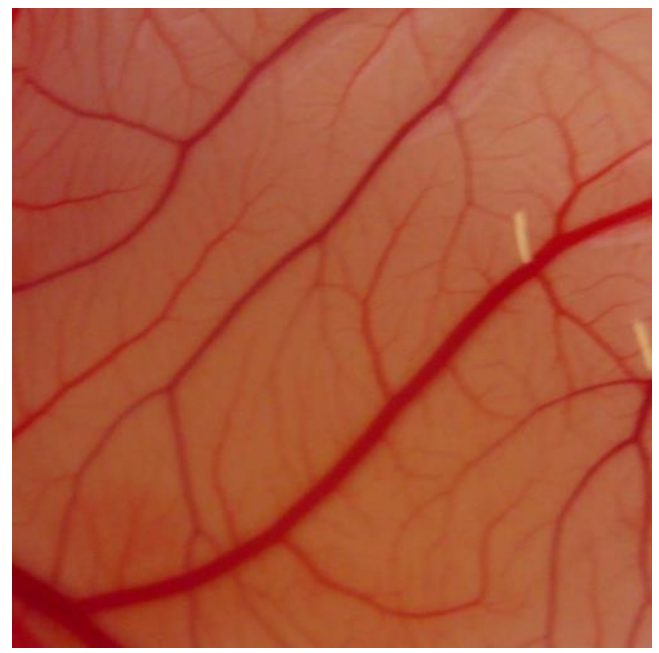

Image 2. The representation of the circulatory system on the $15^{\text {th }}$ day of embryonic development

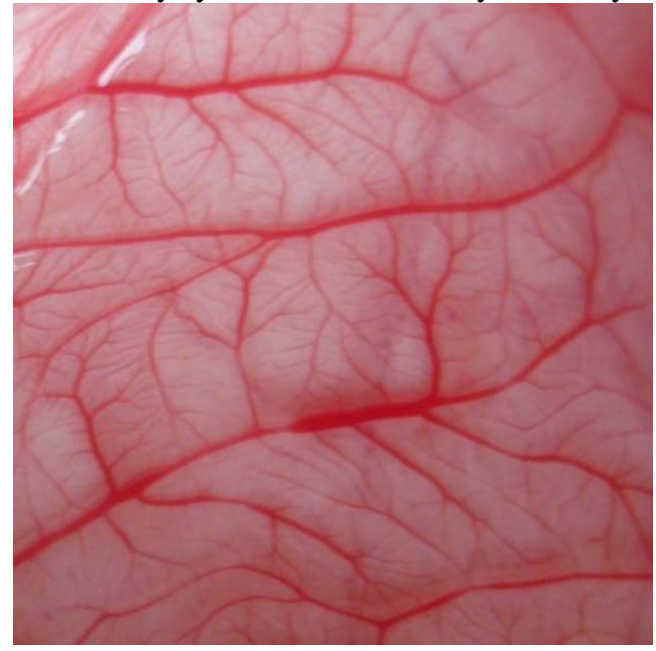

Image 3. The representation of the circulatory system on the $19^{\text {th }}$ day of embryonic development

\section{DISCUSSION}

This experiment involved a quantitative determination of the development of the CAM circulatory system in chicken embryos during the three key points of embryonic development (days 12, 15 and 19 of embryonic development), from the aspect of the development of CAM and its corresponding blood vessels, which is conditioned by the functioning of the endocrine system.

CAM is formed between E4 and E5, after which it extends and gradually develops until it completely spreads across the embryo on E12 (Deryugina and Quigly, 2008). In addition, the somatotropic cells were not detected in the chicken embryo hypophysis until the interval between the $10^{\text {th }}$ and the $12^{\text {th }}$ incubation day, when they were still underdeveloped (Malamed et al., 1993), which is significant due to the fact that the growth hormone has a stimulating effect on the angiogenesis (Clapp et al., 2009). Scanes (1997) states that a fast proliferation and differentiation of the somatotropic cells in the bird hypophysis occur on the $15^{\text {th }}$ day of embryonic development (E15). According to Ausprunk et al. (1974), the CAM circulatory system reaches the maximum of its development on the $18^{\text {th }}$ day of embryonic development.

Morphometric CAM examinations in the paper by De Fouv et al. (1989) proved that CAM rapidly increases its surface from $6 \mathrm{~cm}^{2}$, which is its surface on the $6^{\text {th }}$ day of embryonic development, to $65 \mathrm{~cm}^{2}$ on the $14^{\text {th }}$ day of embryonic development. This intensive surface increase is followed by a high angiogenic response, which corresponds to our results. In other words, the circulation index, i.e. the CAM vascularization indicator, increases with embryonic age. The CAM angiogenesis occurs by means of two mechanisms. During the first part of the incubation, a large number of capillaries split, thus invading the mesenchyme; next, they fuse and form the primary 
capillary plexus. In the second part of incubation, the splitting is replaced by intussusceptive microvascular growth (IMG), which provides a rich network of capillaries (Makanya et al., 2009).

According to Makanya et al. (2016), the CAM development can be divided into 3 phases based on allometric analyses. The first phase is the period between the $8^{\text {th }}$ and the $13^{\text {th }}$ day of embryonic development and it involves a rapid proliferation and growth of CAM. Our first sample for the determination of CAM circulation index was collected during this particular phase, i.e. on the $12^{\text {th }}$ embryonic day and its amount was 0.1952. Ribatti (2016) believes that the fibroblast growth factor 2 (FGF-2) is very important for the development of CAM blood vessels in this phase and that its increased value can be detected between the $6^{\text {th }}$ and the $8^{\text {th }}$ incubation day. The maximum values of this factor can be detected between the $10^{\text {th }}$ and the $14^{\text {th }}$ embryonic development day, which also corresponds to the moment of our first CAM sample collection for stereological examination. Baum et al. (2010) state the importance of another factor - the vascular endothelial growth factor A (VEGF-A), in which case we can detect two peaks on the $8-9^{\text {th }}$ and $11-12^{\text {th }}$ embryonic development day.

The second phase begins on the $13^{\text {th }}$ day and lasts until the 18 th day of embryonic development according to Makanya et al. (2016). In this phase, the processes of differentiation, growth and expansion of all CAM parts are more intense and on the $18^{\text {th }}$ day of embryonic development, this phase reaches its peak. The results of our study for the $15^{\text {th }}$ day of embryonic development correspond to this phase and it can be noted that the circulation index value is higher than on the $12^{\text {th }}$ day of embryonic development at the level of statistical significance $\mathrm{P}<0.05$. These results are in accordance with the development phases determined by Makanya et al. (2016). Phase 3 lasts from the $18^{\text {th }}$ incubation day until hatching. This phase involves the regression and degeneration of CAM. Our circulation index results obtained during the last sampling correspond to this phase of CAM development and the circulation index is higher on the $19^{\text {th }}$ day of embryonic development when compared to the $12^{\text {th }}$ day of embryonic development $(\mathrm{P}<0.01)$ and to the $15^{\text {th }}$ day of embryonic development $(\mathrm{P}<0.05)$. The possible explanation of these results is that there is no regression and degeneration of CAM blood vessels, as is the case of stromal components of the mesoderm and the chorionic and allantoic epithelium and that the blood vessels are maintained or that angiogenesis is more intense. Another possible explanation would be that angiogenesis reaches its peak on the $18^{\text {th }}$ day of embryonic development and that it is followed by gradual regression; this could be considered a more possible theory because the embryo gradually prepares for hatching. Namely, just before hatching, at the moment when the embryo breaks the air cell with its beak, the respiratory function of lungs is activated, i.e. CAM loses its gas exchange function (internal pipping). In their study, Makanya et al. (2016) notice a higher level of apoptosis both in chorionic epithelium and in allantoic epithelium on the 18th day of embryonic development. However, they also notice apoptotic cells in CAM mesenchyme. The claim that regression and degeneration of blood vessels occur in this phase could not be confirmed by the results of this study because CAM sampling was not performed on the 18th day of embryonic development.

This study raises the possibility of further research and improvement of the method for the quantification of CAM angiogenesis. In the future, it would be necessary to determine the chicken CAM circulation index for all embryonic development days, as well as to standardize all the conditions in the course of processing the pictures, so that the results of various researches could be compared. In addition, this method could be applied to other bird species in order to conduct comparative research, and it could also become a new method in pharmacological, toxicological, and angiogenic studies.

\section{CONCLUSION}

The applied method is a simple, objective, and precise method for the determination of CAM circulation. The efficiency of this method is reflected in the fact that it is suitable for examining a large number of samples because the preparation of CAM and the picture processing are not time-consuming. The results of our study indicate that the progress of embryonic age implies an increase of circulation index, which is also an indicator of angiogenic processes occurring in CAM. In other words, the lowest circulation index value $(0.1952)$ was marked on the first sampling day (E12), while the largest value (0.2666) was marked on the last sampling day (E19). This kind of CAM blood vessel development potential is in accordance with the data found in the reference papers, which confirms the validity of this method even further. In conclusion, this method may be applied in order to examine different incubation factors of CAM angiogenesis, which can be related to postnatal performance.

\section{REFERENCES}

AUSPRUNK DH, KNIGHTON DR, FOLKMAN J: Differentiation of vascular endothelium in the chick chorioallantois: a structural and autoradiographic study. Dev. Biol., 38: 237-248, 1974.

BAUM O, SUTER F, GERBER B, TSCHANZ SA, BUERGY R, BLANK F, HLUSHCHUK R, DJONOV V: VEGF-A promote 
intussusceptive angiogenesis in the developing chicken chorioallantoic membrane. Microcirculation 7: 447-457, 2010.

BURITY CHF, PISSINATTI A, MANDARIM-DE-LACERDA CA: Stereology of the Liver in Three Species

of Leontopithecus (Lesson, 1840) Callitrichidae - Primates. Anatomia, Histologia, Embryologia, 33: 183-187, 2004.

CLAPP C, THEBAULT S, JEZIORSKI MC, MARTÍNEZ DE LA ESCALERA G: Peptide hormone regulation of angiogenesis. Physiol Rev, 89(4):1177-1215, 2009.

De FOUW DO, RIZZO VJ, STEINFELD R, FEINBERG RN: Mapping of the microcirculation in the chick chorioallantoic membrane during normal angiogenesis. Microvasc Res, 38:136-147, 1989.

De SMIT L, BRUGGEMAN V, TONA JK, DEBONNE M, ONAGBESAN O, ARCKENS L, De BAERDEMAEKER J,

DECUYPERE E: Embryonic developmental plasticity of the chick: increased CO2 during early stages of incubation changes the developmental trajectories during prenatal and postnatal growth. Comp Biochem Physiol Part A Mol Integr Physiol, 145:166-175, 2006.

DERYUGINA EI, QUIGLEY JP: Chick embryo chorioallantoic membrane model systems to study visualise human tumor cell metastasis. Histochem Cell Biol, 130(6):1190-1130, 2008.

HULET RM: Managing incubation: Where are we and why? Poult Sci, 86:1017-1019, 2007.

KANAČKI Z, STOJANOVIĆ S, UŠĆEBRKA G, ŽIKIĆ D: The effect of modification of incubation factors on the quality of broiler chickens meat. $3^{\text {rd }}$ International Congress: "New perspectives and challenges of sustainable livestock production", Belgrade, Serbia, 5-7 October, 2011. Biotechnology in Animal Husbandry, 27 (4):1605-1611, 2011.

MAKANYA AN, DIMOVA I, KOLLER T, STYP-REKOWSKA B, DJONOV V: Dynamics of the Developing Chick Chorioallantoic Membrane Assessed by Stereology, Allometry, Immunohistochemistry and Molecular Analysis. PloS ONE, 11(4):e0152821, 2016.

MAKANYA AN, HLUSHCHUK R, DJONOV VG: Intussusceptive angiogenesis and its role in vascular morphogenesis, patterning, and remodeling. Angiogenesis, 12(2):113-123, 2009.

MALAMED S, GIBNEY JA, CAIN LD, PEREZ FM, SCANES CG: Immunocytochemical studies of chicken somatotrophs and somatotroph granules before and after hatching. Cell Tissue Res, 272(2):369-374, 1993.

NOWAK-SLIWINSKA P, SEGURA T, IRUELA-ARISPE ML: The chicken chorioallantoic membrane model in biology, medicine and bioengineering. Angiogenesis, 17(4):779-804, 2014.

RIBATTI D: The chick embryo chorioallantoic membrane (CAM). A multifaceted experimental model. Mechanisms of Development, 141:70-77, 2016.

ROMANOFF AL: The avian embryo: structural and functional development. Mc Millan, New York, pp.1039-1141, 1960.

SCANES C: Ontogeny of the Hypothalamic-Pituitary (Growth Hormone)-Insulin-Like Growth Factor-I Axis in Birds. American Zoologist, 37(6): 524-535, 1997.

TUAN RS: Mechanism and regulation of calcium transport by the chick embryonic chorioallantoic membrane. J Exp Zool Suppl, $1: 1-13,1987$.

VERHOELST E, BAMELIS F, KETELAERE BD, TRONG NND, BAERDEMAEKER JD, SAEYS W, TSUTA M,

DECUYPERE E: The potential of spatially resolved spectroscopy for monitoring angiogenesis in the chorioallantoic membrane. Biotechnol Progress, 27:1785-1792, 2011a.

VERHOELST E, De KETELAERE B, DECUYPERE E, De BAERDEMAEKER J: The effect of early prenatal hypercapnia on the vascular network in the chorioallantoic membrane of the chicken embryo. Biotechnol Prog, 27:562-570, $2011 \mathrm{~b}$. 


\title{
INDEKS PROKRVLJENOSTI KAO KVANTITATIVNI POKAZATELJ ANGIOGENEZE U HORIOALANTOISNOJ MEMBRANI TOVNIH PILIĆA
}

\author{
Zoran RUŽIĆ, Zdenko KANAČKI, Dragan ŽIKIĆ, Gordana UŠĆEBRKA, Jovan MIRČETA
}

Izvod: Horialantoisna membrana (CAM) je ekstraembrionalna membrana koja se veoma često koristi za in vivo studije u različitim istraživanjima. Kako je u istraživanjima potreban brz način kvantifikovanja angiogenetskog odgovora CAM, postoji potreba da se razvije nova metoda kvantifikacije angiogeneze u CAM koja će biti precizna i objektivna, da se lako izvodi i da je pogodna za analizu velikog broja uzoraka. Cilj ovog rada je da se primeni nova metoda kvantifikacije angiogeneze radi ispitivanja razvoja krvih sudova CAM u pojedinim danima embrionalnog života, koji se smatraju bitni sa aspekta razvoja CAM. U ovom istraživanju korišćeno je 75 oplođenih jaja teškog hibrida „Ross 308“. Uzorkovanje CAM za stereološke analize vršeno je u kritičnim fazama embrionalnog razvoja odnosno 12., 15. i 19. dana emrionalnog razvoja. Rezultati u našoj studiji ukazuju da se sa povećanjem embrionalne starosti povećava i indeks prokrvljenosti koji je ujedno pokazatelj angiogenetskih procesa koji se odvijaju u CAM. Prvog dana uzorkovanja (E12) zabeležena je najmanja vrednost za indeks prokrvljenosti $(0,1952)$, dok je najveća vrednost $(0,2666)$ zabeležena poslednjeg dana uzorkovanja (E19). Ova metoda može naći svoju primenu u ispitivanju različitih faktora na angiogenezu u CAM.

Ključne reči: horioalantoisna membrana, indeks prokrvljenosti, angiogeneza, angiogenetski odgovor

Received / Primljen: 13.03.2017.

Accepted / Prihvaćen: 11.06.2018. 